\title{
Protective effect of Emblica-officinalis in arsenic induced biochemical alteration and inflammation in mice
}

\author{
Manish K. Singh', Suraj Singh Yadav', Rajesh Singh Yadav², Abhishek Chauhan', Devendra Katiyar \\ and Sanjay Khattri ${ }^{*}$
}

\begin{abstract}
Exposure to arsenic in individuals has been found to be associated with immune related problems. In earlier studies, we have demonstrated that amla protects against arsenic induced oxidative stress and apoptosis in thymus and spleen of mice. In continuation to that the present study has therefore been focused to investigate the protective efficacy of amla in arsenic induced inflammation and immunotoxicity in mice. The results showed that arsenic treatment significantly increased serum urea levels (69\%), glucose levels (48\%) and triglyceride levels (66\%) as compared to controls. Mice exposed to arsenic exhibited significant increased in TNF- $\alpha$ (4.3-fold), serum Interleukin-1 beta (threefold), Interleukin-6 (3.8-fold) as compared to controls. Arsenic exposure increased the relative frequency of CD8+ (Tc) cells sub-population (18.9\%) and decreased CD4+ (Th) cells (2.6\%). Arsenic exposure also significantly decreased $\mathrm{T}$ (CD3) and B (CD19) cells (21.1\%) as compared to controls. Simultaneously treatment with arsenic and amla significantly inhibited serum urea levels (47 \%), glucose levels (50 \%) and triglyceride levels ( $14 \%$ ). It also significantly decreased the TNF- $\alpha$ (1.1-fold), levels of IL-1 $\beta$ (1.6-fold), levels of Interleukin-6 (1.3-fold) in serum as compared to those treated with arsenic alone. Simultaneously treatment with arsenic and amla restored the alterations in CD8+ and CD4+ cells and also recovered the damages in B and T sub cells population. Results of the present study clearly indicate that arsenic induced immunotoxicity linked with inflammation has been significantly protected through simultaneous treatment with arsenic and amla that was due to anti-inflammatory and antioxidant activity of amla.
\end{abstract}

Keywords: Arsenic, Amla, Inflammation, Immunotoxicity, Mice

\section{Background}

Arsenic, a naturally occurring metalloid exists in three oxidation states (elemental, trivalent and pentavalent). It is widely present in rocks, soil and ground water due to geochemical composition and its contamination is associated with the global health concern which affects millions of people across the worldwide (Rahman et al. 2010; Yadav et al. 2011; Srivastava et al. 2014). Persons from low economic position and malnourishment have found to be more vulnerable towards the toxic effect of arsenic as such population have mainly depends on the

\footnotetext{
*Correspondence: drskhattri01@gmail.com

${ }^{1}$ Department of Pharmacology, King George Medical University,

Lucknow 226 003, UP, India

Full list of author information is available at the end of the article
}

available arsenic contaminated water (Sakurai et al. 2005; Zablotska et al. 2008). After entering the body, arsenic is rapidly undergoes to the metabolic conversion through the process of biotransformation where it converts into toxic arsenite and then transformed into mon-, di-, and trimethylated products (Thomas et al. 2004; Sakurai et al. 2005). Further, it redistributes itself to the entire organ systems of the body and also accumulates in some organs (Ratnaike 2003). Exposure of arsenic to individuals increased the generation of reactive oxygen species and nitric oxide and involved in the production of proinflammatory cytokines (Marnett et al. 2003; Islam et al. 2007; Palmieri et al. 2007). Elevated levels of interleukin 6 (IL-6) and tumor necrosis factor alpha (TNF $\alpha$ ), produced by the immune system play an important role in increasing the risk of cardiovascular disease. Both IL-6

\section{贷 Springer}


and TNF $\alpha$ involves in the regulation of the synthesis of other acute phase proteins which could established risk factors for atherosclerosis (Baumann and Gaildie 1994). Alterations in both the intracellular and intercellular homeostasis of these factors leads to possible cell death, inhibition of enzymes, mitochondrial functions and thus enhance the induction of several stress genes (Liu et al. 2001; Singh et al. 2013; Srivastava et al. 2014).

Arsenic exposure in individuals have been reported to cause fetal death due to increased placental inflammatory response, reduced placental $\mathrm{T}$ cells and altered levels of cord blood cytokines (Escobar et al. 2010; Ahmed et al. 2011). Arsenic exposure in pregnant may increased the risk of infectious diseases in both mothers and children, indicating arsenic related immunosuppression (Moore et al. 2009; Raqib et al. 2009; Rahman et al. 2010). Immune related disorders associated with poor development of thymus in infants during the pregnancy in arsenic exposed population have also been reported in epidemiological studies (Andrew et al. 2008; Moore et al. 2009; Banerjee et al. 2011). Studies have been reported that chronic exposure to arsenic impairs lymphocyte, monocyte, and macrophage activity and also affects cellular immune responses in mammals, resulting in immunosuppression (Lemarie et al. 2006; Sakurai et al. 2006; Selgrade 2007; Burchiel et al. 2009; Qian et al. 2010). A reduction in $\mathrm{CD} 4+$ cell counts, $\mathrm{CD} 4+: \mathrm{CD} 8+$ cell ratios, and T-regulatory cell levels has been reported in adults and children following exposure to arsenic (McCollum et al. 2005; Hernandez-Castro et al. 2009). Susceptibility of activation of inflammatory cytokines involved in immune related disorders have been reported in humans and rodents exposed to arsenic (Fry et al. 2007).

In recent years, a number of plant products, their active constituents and herbal agents have been used to protect against arsenic induced toxicity (Sharma et al. 2009; Singh et al. 2013, 2014a; Srivastava et al. 2014). The fruit extract of Emblica officinalis and its active constituents have long been used in Chinese and Indian traditional system of medicine and has shown anti-oxidative, antiinflammatory, anti-cancer and immunomodulatory properties (SaiRam et al. 2002; Sreeramulu and Raghunath, 2009; Singh et al. 2013, 2014a). Amla is a rich source of Vitamin C, a water soluble anti-oxidant, a wide variety of phenolics like anthocyanins, flavonols, ellagic acid and its derivatives that acts as a scavenger of free radicals and plays an important role to protect against lipid damage, protein oxidation and DNA oxidation (Sreeramulu and Raghunath 2009; Singh et al. 2013, 2014a). We have recently reported that arsenic induced enhanced oxidative stress linked with apoptosis in thymocytes of mice has been found to be protected through treatment with amla (Singh et al. 2013, 2014a). Arsenic induced hepatic toxicity associated with its accumulation in the liver and impaired antioxidant status has also been found to be protected following simultaneous treatment with arsenic and amla (Singh et al. 2014b). The anti-oxidant potential of amla and its various constituents have been reported but not much is known about its role on inflammatory cytokines in arsenic induced toxicity. Present study has therefore been carried out to understand the protective role of the fruit extract of amla in arsenic induced inflammation and immunotoxicity in mice.

\section{Methods}

\section{Animals and treatment}

The present study was approved by the institutional animal ethics committee of King George Medical University, Lucknow (No. 121 IAH/Pharma-11), India, and all experiments were carried out in accordance with guidelines set by the Committee for the Purpose of Control and Supervision of Experiments on Animals (CPCSEA), Ministry of Environment and Forests (Government of India), New Delhi, India. Male Balb/c mice (15 \pm 2 g) were obtained from the animal breeding colony of CSIR-Indian Institute of Toxicology Research, Lucknow. Mice were housed in an air-conditioned room at $25 \pm 2{ }^{\circ} \mathrm{C}$ with a $12 \mathrm{~h} \mathrm{light/}$ dark cycle under standard hygiene conditions and had ad libitum access to a pellet diet and filtered water. The dose of fruit extract of Embilica officinalis and arsenic is based on our previous findings (Singh et al. 2013, 2014a) for the present study. The mice were randomly divided into four groups with 10 animals/group and the dose of arsenic and amla were given with the help of canola after dissolving in suitable solvent:

- Group I-Mice treated with vehicle (2 \% gum acacia) for duration of treatment and served as control.

- Group II-Mice treated with sodium arsenite (dissolved in distilled water at $3 \mathrm{mg}$ arsenic/kg body weight, per os daily for 30 days).

- Group III-Mice treated with fruit extract of Emblica officinalis (500 mg/kg body weight, suspended in $2 \%$ gum acacia, per os daily for 30 days).

- Group IV-Mice co-treated daily with arsenic and fruit extract as in Groups II and III.

\section{Blood/tissues collection}

At the end of the experimental period (30 days), a set of animals were sacrificed by cervical dislocation. In another set, after heart puncher blood was quickly collected in 10 \% EDTA tubes for the separation of serum. For the assessment of different inflammatory markers, the thymus and spleen were isolated from mice following the procedure of Pathak and Khandelwal (2009). The thymus and spleen of five mice/groups were cleaned and 
placed in phosphate-buffered saline (PBS, pH 7.4) and subsequently processed for measures of immunological parameters. The remaining thymus and spleen in each set were placed in ice-cold saline solution $(0.15 \mathrm{M})$, blotdried, weighed, and then immediately processed for use in assessment of arsenic level in both tissues.

\section{Preparation of thymocyte splenocytes suspension}

The dissected thymus and spleen from mice and single cell suspension were prepared under aseptic condition. The suspension were passed through stainless steel mesh centrifuged at $200 \times g$ at $4{ }^{\circ} \mathrm{C}$ for 10 min thymocytes resuspended in PBS. Splenocytes were suspended in $5.0 \mathrm{ml}$ hypotonic erythrocyte lysing solution $(2.42 \mathrm{~g}$ Tris and $7.56 \mathrm{~g} \mathrm{NH} 4 \mathrm{Cl}$ in $1.0 \mathrm{l}$ deionised water, $\mathrm{pH}$ adjusted to 7.2). After 5 min incubation followed by centrifugation, cells were resuspended in PBS, counted through a hemocytometer and then diluted with PBS to appropriate concentrations for use in immunological assays.

\section{Assay of serum biochemical parameters}

Serum samples collected from the blood were subjected to biochemical estimations of serum urea, glucose and TG level and the activity of serum were measured through fully automated biochemical analyzer (CHEMWELL1520, USA). All serum samples were analyzed in duplicate and then mean values were taken.

\section{Assay of nitric oxide levels}

Levels of nitric oxide in serum were estimated using the nitric oxide assay kit procured commercially (Calbiochem, USA) following the method of Misko et al. (1993). The assay principle involves the conversion of nitrate to nitrite by the enzymatic action of nitrate reductase. Addition of 2,3-diaminonaphthalene (DAN) and sodium hydroxide converts nitrite to a fluorescent compound $1(\mathrm{H})$-naphthotriazole which is measured spectroflurometrically (excitation $430 \mathrm{~nm} /$ emission $450 \mathrm{~nm}$ ) using multi well plate reader. The results are expressed as $\mathrm{p}$ mole nitrate/mg tissue weight.

\section{Cytokine determination}

The parameters related with the cytokine determination have been carried out following the method of Singh et al. (2010a, b).

\section{Assay of serum Interleukin-1 beta (IL-1 $\beta$ )}

The levels of Interleukin-1 beta in serum of mice exposed to arsenic and simultaneous treatment of arsenic and amla were estimated by using the Quantikine mouse IL-1 $\beta$ kit obtained from R\&D systems. This assay employs the quantitative sandwich enzyme immunoassay technique (ELISA). An affinity purified polyclonal antibody specific for mouse IL-1 $\beta$ pre-coated plates was used. The intensity of the colour measured was in proportion to the amount of mouse IL- $1 \beta$ bound to the sample.

\section{Assay of serum Interleukin-6 (IL-6)}

The levels of Interleukin- 6 in serum of mice exposed to arsenic and simultaneous treatment of arsenic and amla were quantified by using an enzyme linked immunosorbent assay (ELISA) method through the Quantikine mouse IL-6 kit obtained from R\&D systems. The intensity of the colour measured was in proportion to the amount of mouse IL- 6 bound to the sample. The levels of IL- 6 were calculated using a standard curve.

\section{Assay of serum tumor necrosis factor-alpha (TNF- $\alpha$ )}

The quantitative measurements of the level of TNF- $\alpha$ in serum of mice were performed by using the solid phase ELISA. This assay employs the quantitative sandwich enzyme immunoassay technique. The 96 -well pre-coated plate with polyclonal antibody specific for mouse TNF- $\alpha$ was used. The intensity of the colour measured was in proportion to the amount of serum TNF- $\alpha$ bound to the sample. The levels of TNF- $\alpha$ were calculated using a standard curve.

\section{Assessment of T and B lymphocyte population in thymocytes and spleenocytes}

T-cells phenotyping were conducted on the basis of CD4 and CD8 surface molecules. Positioning of quadrants on FITC/PE dot plots were performed and CD4+CD8+ (double positive; DP) and CD4CD8 - (double negative; DN) sub-populations were distinguished. The lymphocyte population of splenocytes were assessed based on CD3 (for T-cells) and CD19 (for B-cells) surface molecules. Briefly, cells were suspended in $1 \mathrm{ml}$ PBS. An aliquot of $100 \mu \mathrm{l}$ was incubated with $5 \mu \mathrm{l}$ FITC-conjugated anti-CD4 monoclonal antibody and $5 \mu \mathrm{l}$ PE-conjugated anti- CD8 monoclonal antibody for thymocytes. On the other hand, splenocytes were incubated with $5 \mu \mathrm{l}$ FITC-conjugated anti-CD3 monoclonal antibody and $5 \mu \mathrm{PE}$ conjugated anti-CD19 monoclonal antibody separately for $30 \mathrm{~min}$ in dark at room temperature. After incubation, $400 \mu \mathrm{l}$ PBS was added to each sample. The FITC and PE fluorescence were measured through FL-1 filter $(530 \mathrm{~nm})$ and FL-2 filter $(585 \mathrm{~nm})$, respectively, on flow cytometer and 10,000 events were acquired. The data were analysed on Cell Quest software and mean fluorescence intensity was obtained by histogram statistics.

\section{Estimation of arsenic levels in thymus and spleen}

Arsenic levels in thymus and spleen of mice exposed to arsenic and simultaneous treatment of arsenic and amla 
were estimated by hydride system 60 atomic absorption spectrophotometer (HSAAS, ZEEnit 700) following the method of Ballentine and Burford (1957). Briefly, $1 \mathrm{ml}$ of concentrated nitric acid was added followed by $1 \mathrm{ml}$ of perchloric acid to $100 \mathrm{mg}$ of tissue. The sample was then digested over a sand bath until the solution became yellow in colour. If the colour of the digest was brown, more nitric acid and perchloric acid were added and the oxidation was repeated. The digest was made up to known volume with deionized water. Aliquots of this were used to estimate arsenic using atomic absorption spectrophotometer. A calibration curve was constructed by adding known amounts of arsenic standard to calculate arsenic levels in the thymus and spleen regions.

\section{Statistical analysis}

Data were analyzed using one-way analysis of variance (ANOVA) followed by a Newman-Keuls test for multiple pair-wise comparisons among the groups. All values were expressed as mean $( \pm$ SEM $) . P<0.05$ was considered significant.

\section{Results \\ Effect on the levels of nitric oxide}

The levels of nitric oxide as a measure of enhanced oxidative stress has been measured and presented in Fig. 1. Mice exposed to arsenic exhibited significant increases in nitric oxide levels (55\%, p < 0.001) as compared to controls. Simultaneous treatment with arsenic and amla significant decreased the nitric oxide levels $(20 \%, \mathrm{p}<0.05)$ in serum as compared to those treated with arsenic alone. No significant effect on nitric oxide levels was observed in mice treated with amla alone as compared to controls (Fig. 1).

\section{Effect on the serum biochemical level in mice}

The effect on the serum biochemical level in mice following exposure to arsenic has been represented in Fig. 2. The results showed that arsenic treatment significantly increased serum urea level $(69 \%, \mathrm{p}<0.001)$, glucose level $(48 \%, \mathrm{p}<0.001)$, triglyceride (TG) level $(66 \%, \mathrm{p}<0.001)$ compared to the control group. Simultaneously treatment with arsenic and amla significantly inhibited serum urea level $(47 \%, \mathrm{p}<0.001)$, glucose level $(50 \%$, $\mathrm{p}<0.001)$ and TG level $(14 \%, \mathrm{p}<0.05)$ as compared to mice treated with arsenic alone. No significant effect was observed in mice treated with amla alone as compared to controls (Fig. 2).

\section{Effect on tumor necrosis factor-alpha in serum of mice}

Effect of arsenic and co-treatment of arsenic and amla on TNF- $\alpha$ level in the serum has been presented in Fig. 3. Mice exposed to arsenic exhibited significant increases in

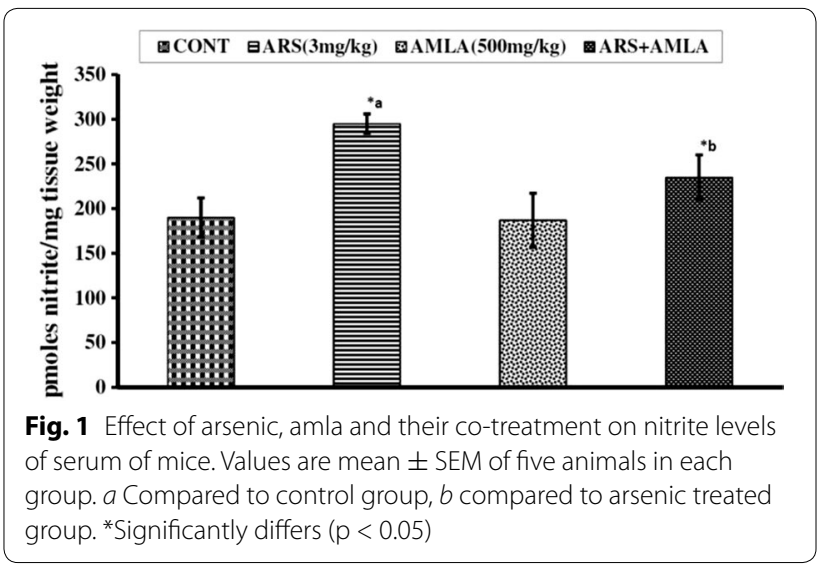

TNF- $\alpha$ (4.3-fold, $\mathrm{p}<0.001)$ as compared to controls. Cotreatment with arsenic and amla significant decreases the TNF- $\alpha(1.1$-fold, $\mathrm{p}<0.05)$ in serum as compared to those treated with arsenic alone. No significant effect on serum TNF- $\alpha$ was observed in mice treated with amla alone as compared to controls (Fig. 3).

\section{Effect on Interleukin-1 beta in serum of mice}

Figure 4 indicates the effect of arsenic and co-treatment of arsenic and amla on reduced serum level of interleukin- $1 \beta$ of mice. Exposure to arsenic in mice caused a significantly increases in the levels of serum Interleukin-1 beta (threefold, $\mathrm{p}<0.001$ ) in mice as compared to controls. Co-treatment with arsenic and amla decreases the levels of IL- $1 \beta$ ( 1.6 -fold, $p<0.001$ ) in serum of mice as compared to those treated with arsenic alone. No significant effect on the levels of Interleukin-1 beta was observed in the mice treated with amla alone as compared to controls (Fig. 4).

\section{Effect on Interleukin- 6 in serum of mice}

Effect of arsenic and co-treatment of arsenic and amla on the serum level of Interleukin-6 in mice has been presented in Fig. 5. Exposure of arsenic to mice caused an increased the serum level of Interleukin-6 (3.8-fold, $\mathrm{p}<0.001)$ as compared to controls. Co-treatment with arsenic and amla decreased the serum level of Interleukin-6 $(1.3$-fold, $\mathrm{p}<0.001)$ as compared to mice treated with arsenic alone suggested the antioxidant activity of amla. No significant effect was observed in mice treated with amla alone as compared to controls (Fig. 5).

\section{Effect on T and B lymphocyte population in thymocytes and spleenocytes of mice}

The effect of arsenic on thymocyte and spleenocytes population in mice was measured by cell surface marker expression using flow cytometry and expressed in 


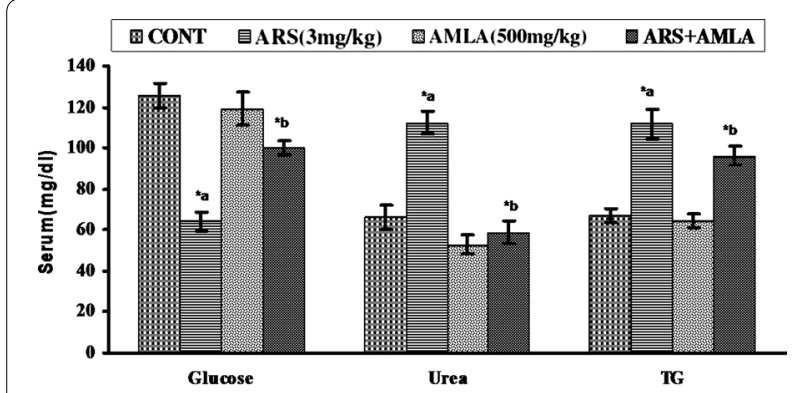

Fig. 2 Effect of arsenic, amla and their co-treatment on biochemical estimation in serum of mice. Values are mean \pm SEM of five animals in each group. a Compared to control group, $b$ compared to arsenic treated group. *Significantly differs $(p<0.05)$

Additional file 1: Table S1. Arsenic exposure increased the relative frequency of $\mathrm{CD} 8$ (Tc) cells sub-population
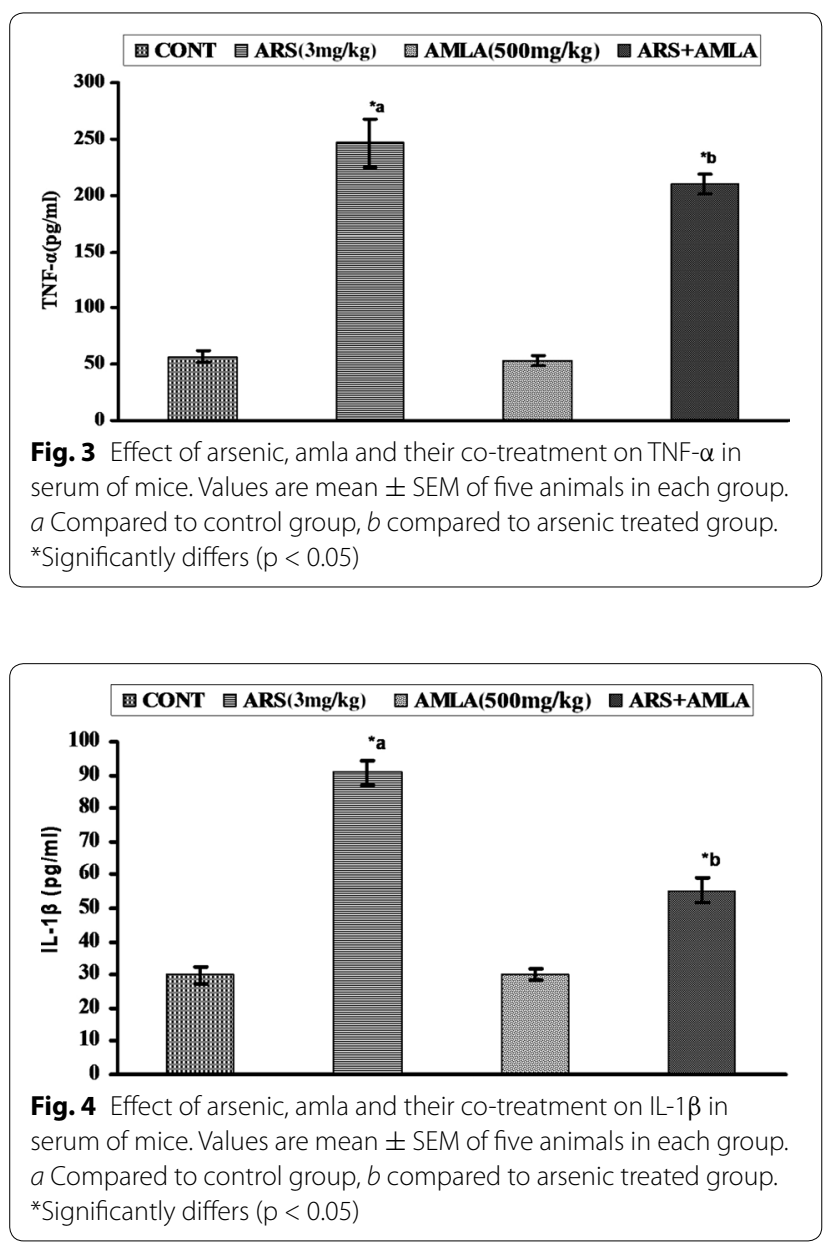

from 2.8 to $18.9 \%$ and decreased CD4(Th) cells from 5.3 to $2.6 \%$ as compared to controls. These distinct phenotypic changes were found to be recovered following simultaneous treatment with arsenic and amla. Both
CD8 and CD4 cell types came close to controls i.e. 2.5 and $3.4 \%$, respectively as compared to arsenic treated group. No significant effect on Th cells and Tc cells ratio was observed in mice treated with amla alone as compared to controls group.

Arsenic treated group significantly decreases T (CD3)and B (CD19)-cells from 35.7 to $21.1 \%$ as compared to controls. Whereas simultaneously treatment with arsenic and amla restored it back to $32.4 \%$. Similarly, the severely affected B cell population was also restored to $50.3 \%$ from $32.5 \%$, by fruit extract of amla. No significant effect on the ratio of $\mathrm{T} / \mathrm{B}$ cells was observed in the mice treated with amla alone as compared to controls group.

\section{Effect on arsenic levels in thymus and spleen of mice}

A significant increase in the levels of arsenic in thymus and spleen (3.5-fold, $\mathrm{p}<0.01$ ), was observed in mice exposed to arsenic for 30 days as compared to controls (Additional file 1: Table S2). Levels of arsenic were found to be significantly decreased in thymus and spleen (1.3fold, $\mathrm{p}<0.05$ ), in mice simultaneously treated with arsenic and amla as compared to mice treated with arsenic alone. No significant change in arsenic levels in the thymus and spleen was observed in mice treated with amla alone as comparison to controls (Additional file 1: Table S2).

\section{Discussion}

Clinical and pre-clinical studies showed that arsenic act as an immunosuppressant and its exposure in individuals caused various immunological disorders at molecular and cellular levels (Islam et al. 2007; Biswas et al. 2008). Arsenic is a potent immunotoxicant which modulates non-specific immune responses and alters the expression of cytokines in time and dose dependent manners (Das et al. 2011). Enhanced oxidative stress resulting from the imbalance between pro- and antioxidant systems leads to the disruption of biological membrane and contributes to inflammation and production of pro- inflammatory cytokines (Chang et al. 2007; Singh et al. 2010a, b). Increased generation of free radicals/reactive oxygen species (ROS) associated with enhanced oxidative stress have been found to be implicated in the induction of apoptosis in both patho and physiologic states (Stepnik et al. 2005; Sharma et al. 2009). Arsenic induced depletion of anti-oxidant defence enzymes including superoxide dismutase, catalase, and glutathione peroxidase associated with apoptosis, immunotoxicity and hepatic damage have been recently reported by us (Singh et al. 2013, 2014a, b). In the present study, arsenic treatment in mice significantly increased the levels of nitric oxide in thymocytes and spleenocytes of mice as compared to the controls further indicates the enhanced oxidative stress. 


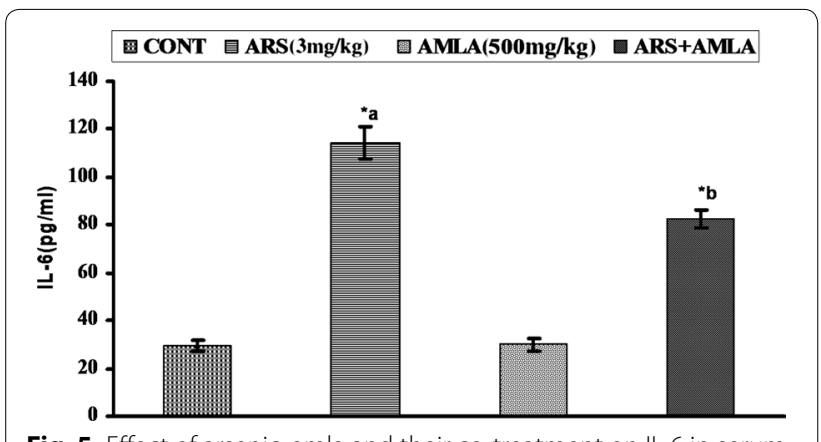

Fig. 5 Effect of arsenic, amla and their co-treatment on IL-6 in serum of mice. Values are mean \pm SEM of five animals in each group. $a$ Compared to control group, $b$ compared to arsenic treated group. *Significantly differs $(p<0.05)$

The alterations in the serum urea level considered as a significant marker of renal dysfunctions. The increased breakdown of tissue, dietary or impaired excretion also found to be linked with the high levels of blood urea (Polliack et al. 1993). The increased urea concentration in serum following treatment with arsenic in mice has been considered due to its effect on liver functions (Sands 1999). In human population, chronic arsenic exposure has been showed to increase blood glucose level (Tseng 2004). Enhanced oxidative stress due to arsenic exposure damages the $\beta$ cells of the pancreatic islets leading to increase blood glucose levels (Hayden and Tyagi 2002). In the present study, arsenic treatment in mice significantly increased the serum urea, glucose and triglyceride level associated with enhanced levels of nitric oxide clearly indicate the increased oxidative burden as compared to the controls are consistent with the earlier studies.

In an epidemiological study, Biswas et al. (2008) reported that chronic arsenic exposure through contaminated drinking water caused immunosuppression and affect the secretion of variety of cytokines in the population. Mitochondria are considered as the prime targets for arsenic toxicity, these cytokines have been found to be involved in the generation of free radicals via mitochondrial respiratory chain reaction (Volk et al. 2000). Further, the pro-inflammatory cytokines including TNF- $\alpha, \mathrm{IL}-1 \beta$ and IL- 6 are also secrets due to the arsenic toxicity and generates inflammatory responses (Duramad et al. 2007; Singh et al. 2010a, b; Das et al. 2012). These pro-inflammatory mediators are involved in the various biological and cellular comebacks including tumor progression, growth factor, transcription factor and activation of proapoptotic proteins (Manna et al. 2000). Studies have been showed that arsenic exposure increased the incidence of autoimmune mediated diseases, increased expression of tumor necrosis factor- $\alpha$ (TNF $\alpha$ ) and Interleukin-8 (IL8) (Bohler et al. 2000; Tseng 2004). Arsenic exposure in mammals impairs the activities of lymphocyte, monocyte, macrophage and affects the cellular immune responses resulting in immunosuppression (Burchiel et al. 2009; Raqib et al. 2009; Qian et al. 2010). In the present study, arsenic treatment in mice significantly increased the levels of TNF- $\alpha$, serum Interleukin-1 beta and Interleukin- 6 . It also increased the relative frequency of $\mathrm{CD} 8+(\mathrm{Tc})$ cells sub-population and decreased CD4+(Th), T (CD3) and B (CD19) cells as compared to controls.

Studies have been reported the protective efficacy of herbal extracts and synthetic agents in arsenic induced oxidative damage and inflammation (Flora and Gupta 2007; Sharma et al. 2009; Yadav et al. 2009; Singh et al. 2013, 2014a; Srivastava et al. 2014). Amla is widely accepted as an immune enhancer and have multiple pharmacological and immunomodulatory properties due to the presence of various phenolics and its derivatives (SaiRam et al. 2002; Sharma et al. 2009; Sreeramulu and Raghunath 2009; Singh et al. 2013). Toxicity produced through exposure of ethanol, carbon tetrachloride, or hexachlorocyclohexane have been found to be protected following treatment with amla (Pramyothin et al. 2006; Anilkumar et al. 2007). Oxidative effects of arsenic have been found to be counteracted by plant extracts and pharmacological agents due to their antioxidant potential and metal binding property (Flora and Gupta 2007; Sinha et al. 2008). Amla constitutes vitamin $\mathrm{C}$ which mainly acts as an antioxidant compound and has binding affinity with arsenic. The deficiencies of vitamin c may cause hyperlipidaemia and liver dysfunctions (Sharma et al. 1989, 1990). Simultaneous exposure of antioxidant like vitamins $\mathrm{C}, \mathrm{E}$ and some essential metal such as zinc has been found to be beneficial in increasing arsenic mobilization and assisting the recovery of altered biochemical levels during chelating therapy (Kannan and Flora 2004; Modi et al. 2005). We have recently reported the immunomodulatory and anti-oxidative potential of amla against arsenic induced oxidative stress and apoptosis in thymocytes and spleenocytes of mice (Singh et al. 2013, 2014a). In the present study simultaneously treatment with arsenic and amla significantly inhibited the serum urea, glucose, TG and levels of TNF- $\alpha$, IL- $1 \beta$ and Interleukin- 6 in serum. At the same time the arsenic induced alterations in CD8+ and CD4+ cells and damage in $\mathrm{B}$ and $\mathrm{T}$ cells population has been found to be recovered following simultaneous treatment with arsenic and amla as compared to those treated with arsenic alone. One of the most interesting observations in our study is the ability of amla to reduce the concentration of arsenic in the thymus and spleen tissue through decreased arsenic burden in target tissues by metal chelating properties which may play a crucial role in its immunoprotective effect. 


\section{Conclusions}

We can conclude from the present study that arsenic induced immunotoxicity linked with inflammation has been significantly protected through simultaneous treatment with arsenic and amla that was due to antiinflammatory and antioxidant activity of amla. The metal binding property of amla could reduce the load of arsenic in spleen and thymus and help to decrease the generation of reactive oxygen and nitrogen species associated with the oxidative stress and imparts its protective effects. Amla may modulate inflammatory responses by decreasing the production of several chemokines, preventing infiltration of immune cells to the damaged area, and promoting the generation of immunoprotective cytokines to accelerate the repair process. As the mechanism of prevention is not clearly understood, further studies are required to investigate the detailed mechanism of immunoprotection of amla in arsenic induced immunotoxicity.

\section{Additional file}

Additional file 1. Table S1. The effect of arsenic, amla and their co-treatment on the assessment of Th/Tc (CD4+/CD8+) cells ratio in thymocytes and T and B cells in splenocytes of mice are presented. Table S2. Assessment of arsenic level in thymus and spleen of mice after the treatment of arsenic, amla and co-treatment are presented.

\section{Authors' contributions}

MKS: designed the experiment; MKS and SSY conducted research and drafting of the manuscript; RSY: acquisition of data; analysis and interpretation of data; statistical analysis; AC and DK: review of the manuscript; analysis and interpretation of data; obtained funding; administrative support; study supervision. All authors read and approved the final manuscript.

\section{Author details}

1 Department of Pharmacology, King George Medical University, Lucknow 226 003, UP, India. ${ }^{2}$ Department of Criminology and Forensic Science, School of Applied Sciences, Dr. Harisingh Gour Central University, Sagar 470 003, MP, India.

\section{Acknowledgements}

The authors thank to Head, Department of Pharmacology, King George Medical University, Lucknow, India for his interest in the study. The authors are also thankful to Dr. P.C. Choudhury, Professor, Government Ayurvedic College and Hospital, Lucknow, India. Manish Kumar Singh is grateful to the Indian Council of Medical Research, New Delhi for the award of research fellowship. The technical support by Mr. Veerendra Kumar Saini and Mr. Durgesh Yadav is also acknowledged.

\section{Compliance with ethical guidelines}

\section{Competing interests}

The authors declare that they have no competing interests.

Received: 31 March 2015 Accepted: 10 August 2015

Published online: 21 August 2015

\section{References}

Ahmed S, Mahabbat-e Khoda S, Rekha RS, Gardner RM, Ameer SS, Moore S, Ekstrom EC, Vahter M, Raqib R (2011) Arsenic-associated oxidative stress, inflammation, and immune disruption in human placenta and cord blood. Environ Health Perspect 119:258-264
Andrew AS, Jewell DA, Mason RA, Whitfield ML, Moore JH, Karagas MR (2008) Drinking-water arsenic exposure modulates gene expression in human lymphocytes from a US population. Environ Health Perspect 116:524-531 Anilkumar KR, Nagaraj NS, Santhanam K (2007) Reduction of hexachlorocyclohexane-induced oxidative stress and cytotoxicity in rat liver by Emblica officinalis Gaertn. Indian J Exp Biol 45:450-454

Ballentine-Burfor DD (1957) Determination of metals. Methods Enzymol 3:1002-1035

Banerjee N, Nandy S, Kearns JK, Bandyopadhyay AK, Das JK, Majumdez P, Basu S, Banerjee S, Sau TJ, States JC, Giri AK (2011) Polymorphisms in the TNF-and alpha; and IL 10-gene promoters and risk of arsenic-induced skin lesions and other non-dermatological health effects. Toxicol Sci 121(1):132-139

Baumann H, Gaildie J (1994) The acute phase response. Immunol Today 15:74-80

Biswas R, Ghosh P, Banerjee N, Das JK, Sau T, Banerjee A (2008) Analysis of T-cell proliferation and cytokine secretion in the individuals exposed to arsenic. Hum Exp Toxicol 27(5):381-386

Bohler T, Waiser J, Hepburn H, Gaedeke J, Lehmann C, Hambach P (2000) TNFalpha and IL-1alpha induce apoptosis in subconfluent rat mesangial cells. Evidence for the involvement of hydrogen peroxide and lipid peroxidation as second messengers. Cytokine 12:986-991

Burchiel SW, Mitchell LA, Lauer FT, Sun X, McDonald JD, Hudson LG, Liu KJ (2009) Immunotoxicity and biodistribution analysis of arsenic trioxide in C57BI/6 mice following a 2-week inhalation exposure. Toxicol Appl Pharmacol 241:253-259

Chang SI, Jin B, Youn P, Park C, Park JD, Ryu DY (2007) Arsenic-induced toxicity and the protective role of ascorbic acid in mouse testis. Toxicol Appl Pharmacol 218:196-203

Das S, Pan D, Bera AK, Rana T, Bhattacharya D, Bandyapadyay S, De S, Sreevatsava V, Bhattacharya S, Das SK, Bandyopadhayay S (2011) Sodium arsenite mediated immunodisruption through alteration of transcription profile of cytokines in chicken splenocytes under in vitro system. Mol Biol Rep 38:171-176

Das N, Paul S, Chatterjee D, Banerjee N, Majumder NS, Sarma N, Sau TJ, Basu S, Banerjee S, Majumder P, Bandyopadhyay AK, States JC, Giri AK (2012) Arsenic exposure through drinking water increases the risk of liver and cardiovascular diseases in the population of West Bengal, India. BMC Public Health 12:639

Duramad P, Tager IB, Holland NT (2007) Cytokines and other immunological biomarkers in children's environment health studies. Toxicol Lett 172:48-59

Escobar J, Varela-Nallar L, Coddou C, Nelson P, Maisey K, Valdes D, Aspee A, Espinosa V, Rozas C, Montoya M, Mandiola C, Rodríguez FE, Acuna-Castillo C, Escobar A, Fernández R, Diaz H, Sandoval M, Imarai M, Rios M (2010) Oxidative damage in lymphocytes of copper smelter workers correlated to higher levels of excreted arsenic. Mediators Inflamm 40:3830

Flora SJS, Gupta R (2007) Beneficial effects of Centella asiatica aqueous extract against arsenic-induced oxidative stress and essential metal status in rats. Phytother Res 21:980-988

Fry RC, Navasumrit P, Valiathan C, Svensson JP, Hogan BJ, Luo M (2007) Activation of inflammation/NF-kappaB signaling in infants born to arsenicexposed mothers. PLoS Genet 3:e207

Hayden MR, Tyagi SC (2002) Islet redox stress: the manifold toxicities of insulin resistance, metabolic syndrome and amylin derived islet amyloid in type 2 diabetes mellitus. J Pancreas 3(4):86-108

Hernandez-Castro B, Doniz-Padilla LM, Salgado-Bustamante M, Rocha D, Ortiz-Perez MD, Jimenez-Capdeville ME et al (2009) Effect of arsenic on regulatory T cells. J Clin Immunol 29(4):461-469

Islam LN, Nabi AHMN, Rahman MM, Zahid MSH (2007) Association of respiratory complications and elevated serum immunoglobulins with drinking water arsenic toxicity in human. J Environ Sci Health A 42:1807-1814

Kannan GM, Flora SJS (2004) Chronic arsenic poisoning in the rat: treatment with combined administration of succimers and an antioxidant. Ecotoxicol Environ Saf 58:37-43

Lemarie A, Morzadec C, Bourdonnay E, Fardel O, Vernhet L (2006) Human macrophages constitute targets for immunotoxic inorganic arsenic. J Immunol 177:3019-3027

Liu SX, Athar M, Lippai I, Waldren C, Hei TK (2001) Induction of oxyradicals by arsenic: implication for mechanism of genotoxicity. Proc Natl Acad Sci USA 98:1643-1648 
Manna SK, Mukhopadhyay A, Aggarwal BB (2000) Resveratol suppresses TNF induced activation of nuclear transcription factors NF-kappa B, activator protein-1 and apoptosis: potential role of reactive oxygen intermediates and lipid peroxidation. J Immunol 164P:6509-6519

Marnett LJ, Riggins JN, West JD (2003) Endogenous generation of reactive oxidants and electrophiles and their reactions with DNA and protein. J Clin Invest 111:583-593

McCollum G, Keng PC, States JC, McCabe MJ Jr (2005) Arsenite delays progression through each cell cycle phase and induces apoptosis following G2/M arrest in U937 myeloid leukemia cells. J Pharmacol Exp Ther 313:877-887

Misko TP, Schilling RJ, Salvemini D, Moore WM, Currie MG (1993) A fluorometric assay for the measurement of nitrite in biological samples. Anal Biochem 214(1):11-16

Modi M, Kaul RRK, Kannan GM, Flora SJS (2005) Co-administration of zinc and $\mathrm{N}$-acetylcysteine prevents arsenic induced tissue oxidative stress in male rats. J Trace Elem Med Biol 20:197-204

Moore SE, Prentice AM, Wagatsuma Y, Fulford AJ, Collinson AC, Raqib R (2009) Early-life nutritional and environmental determinants of thymic size in infants born in rural Bangladesh. Acta Paediatr 98(7):1168-1175

Palmieri MA, Tasat DR, Molinari L (2007) Oxidative mechanism of lung macrophages exposed to sodium arsenite. Toxicol In Vitro 21:1603-1609

Pathak N, Khandelwal S (2009) Immunomodulatory role of piperine in cadmium induced thymic atrophy and splenomegaly in mice. Environ Toxicol Pharmacol 28:52-60

Polliack A, Taylor R, Bader D (1993) Analysis of sweat during soft tissue breakdown following pressure ischaemia. J Rehabil Res Dev 30:250-259

Pramyothin P, Samosorn P, Poungshompoo S, Chaichantipyuth C (2006) The protective effects of Phyllanthus emblica Linn. Extract on ethanol induced rat hepatic injury. J Ethnopharmacol 107:361-364

Qian L, Lauer FT, Liu KJ, Burchiel SW (2010) Low-dose synergistic immunosuppression of T-dependent antibody responses by polycyclic aromatic hydrocarbons and arsenic in C57BL/6 J murine spleen cells. Toxicol Appl Pharmacol 245:344-351

Rahman A, Vahter M, Ekström EC, Persson LÅ (2010) arsenic exposure in pregnancy increases the risk of lower respiratory tract infection and diarrhoea during infancy in Bangladesh. Environ Health Perspect. doi:10.1289/ ehp. 1002265

Raqib R, Ahmed S, Sultana R, Wagatsuma Y, Mondal D, Hoque AM (2009) Effects of in utero arsenic expo-sure on child immunity and morbidity in rural Bangladesh. Toxicol Lett 185(3):197-202

Ratnaike RN (2003) Acute and chronic arsenic toxicity. Post grad Med 79:391-396

SaiRam M, Neetu D, Yogesh B, Anju B, Dipti P, Pauline T, Sharma SK, Sarada SK, Ilavazhagan G, Kumar D, Selvamurthy W (2002) Cyto-protectiveand immunomodulating properties of Amla (Emblica officinalis) on lymphocytes: an in vitro study. J Ethnopharmacol 81:5-10

Sakurai T, Ochiai M, Kojima C, Ohta TT, Sakurai MH, Takada NO, Qu W, Wallkes MP, Himeno S, Fujiwara K (2005) Preventive mechanism of cellular glutathione in monomethylarsonic acid-induced cytolethality. Toxicol Appl Pharmacol 206:54-65

Sakurai T, Ohta T, Tomita N, Kojima C, Hariya Y, Mizukami A, Fujiwara K (2006) Evaluation of immunotoxic and immunodisruptive effects of inorganic arsenite on human monocytes/macrophages. Int Immunopharmacol 6:304-315

Sands JM (1999) Urea transport: it's not just "freely diffusible" anymore. News Physiol Sci 14(1):46-47

Selgrade MK (2007) Immunotoxicity: the risk is real. Toxicol Sci 100:328-332

Sharma P, Pramod J, Kothari LK, Ranka R, Sharma S (1989) Hyperlipidaemia in guinea pigs induced by chronic vitamin C deficiency. Ind J Clin Biochem 4:62-64

Sharma P, Pramod J, Sharma PK, Sapra M, Kothari LK (1990) Effect of vitamin C deficiency and excess on liver: a histopathological and biochemical study in guinea pigs fed normal or high cholesterol diet. Ind J Pathol Microbiol 33(4):307-313
Sharma A, Sharma MK, Kumar M (2009) Modulatory role of Emblica officinalis fruit extract against arsenic induced oxidative stress in swiss albino mice. Chemico Biol Interact 180:20-30

Singh N, Kumar D, Lal K, Raisuddin S, Sahu AP (2010a) Adverse health effects due to arsenic exposure: modification by dietary supplementation of jaggery in mice. Toxicol Appl Pharmacol 242:247-255

Singh N, Kumar D, Lal K, Raisuddin S, Sahu AP (2010b) Adverse health effects due to arsenic exposure: modification by dietary supplementation of jaggery in mice. Toxicol Appl Pharmacol 242(3):247-255

Singh MK, Yadav SS, Gupta V, Khattri S (2013) Immunomodulatory role of Emblica officinalis in arsenic induced oxidative damage and apoptosis in thymocytes of mice. BMC Complement Altern Med 13:193

Singh MK, Yadav SS, Yadav RS, Singh US, Shukla Y, Pant KK, Khattri S (2014a) Evaluation of antioxidant and anti-apoptotic properties of Emblica officianils (amla) in arsenic induced spleenomegaly in mice. Toxicol Int 21:8-17

Singh MK, Dwivedi S, Yadav SS, Sharma P, Khattri S (2014b) Arsenic-induced hepatic toxicity and its attenuation by fruit extract of Emblica officinalis (Amla) in mice. Indian J Clin Biochem 29:29-37

Sinha M, Manna P, Sil PC (2008) Protective effect of arjunolic acid against arsenic induced oxidative stress in mouse brain. J Biochem Mol Toxicol 22:15-26

Sreeramulu D, Raghunath M (2009) Antioxidant activity and phenolic content of roots, tubers and vegetables commonly consumed in India. Food Res Int 43:1017-1020

Srivastava P, Yadav RS, Chandravanshi LP, Shukla RK, Dhuriya YK, Chauhan LK, Dwivedi HN, Pant AB, Khanna VK (2014) Unraveling the mechanism of neuroprotection of curcumin in arsenic induced cholinergic dysfunctions in rats. Toxicol Appl Pharmacol 279(3):428-440

Stepnik M, Stanczyk M, Arkusz J, Lewinska D (2005) Assessment of apoptosis in thymocytes and splenocytes from mice exposed to arsenate in drinking water: cyto-toxic effects of arsenate on the cells in vitro. J Environ Sci Health 40(2):369-384

Thomas DJ, Waters SB, Styblo M (2004) Elucidating the pathway for arsenic methylation. Toxicol Appl Pharmacol 198:319-326

Tseng C (2004) The potential biological mechanisms of arsenic-induced diabetes mellitus. Toxicol Appl Pharmacol 197:67-83

VolkT, Hense M, Schuster H, Kox WJ (2000) Secretion of MCP-1 and IL-6 by cytokine stimulated production of reactive oxygen species in endothelial cells. Mol Cell Biochem 206:105-112

Yadav RS, Sankhwar ML, Shukla RK, Chandra R, Pant AB, Islam F, Khanna VK (2009) Attenuation of arsenic neurotoxicity by curcumin in rats. Toxicol Appl Pharmacol 240:367-376

Yadav RS, Sankhwar ML, Shukla RK, Chandravanshi LP, Ansari RW, Shukla PK, Pant AB, Khanna VK (2011) Neuroprotective efficacy of curcumin in arsenic induced cholinergic dysfunctions in rats. Neurotoxicology 32:760-768

Zablotska LB, Chen Y, Graziano JH, Parvez F, Geen AV, Howe GR, Ahsan H (2008) Protective effects of $B$ vitamins and antioxidants on the risk of arsenic-related skin lesions in Bangladesh. Environ Health Perspect 116:1056-1062

\section{Submit your manuscript to a SpringerOpen ${ }^{\circ}$ journal and benefit from:}

- Convenient online submission

$\rightarrow$ Rigorous peer review

- Immediate publication on acceptance

- Open access: articles freely available online

- High visibility within the field

- Retaining the copyright to your article

Submit your next manuscript at springeropen.com 